\title{
THE IMPACT OF THE FINANCIAL CRISIS ON INSIDER TRADING PROFITABILITY IN BELGIUM
}

\author{
Debby Van Geyt ${ }^{1}$, Philippe Van Cauwenberge ${ }^{2}$, Heidi Vander Bauwhede ${ }^{3}$ \\ Department of Accountancy and Corporate Finance, Ghent University, \\ Kuiperskaai 55/E, 9000 Ghent, Belgium \\ E-mails: ${ }^{1}$ debby.vangeyt@ugent.be; ${ }^{2}$ philippe.vancauwenberge@ugent.be \\ (corresponding author); ${ }^{3}$ heidi.vanderbauwhede@ugent.be
}

Received 11 February 2011; accepted 21 December 2011

\begin{abstract}
The 2007 global financial crisis led to a chaotic financial environment characterized by highly uncertain and volatile stock markets. This created additional uncertainty about the fundamental value of shares and potentially increased the benefit of inside information. In this paper, we use event study methodology to examine whether Belgian corporate insiders were able to benefit from these turbulent market conditions. Given the large weight of financial institutions, the Belgian stock market was especially vulnerable to the financial crisis and provides an interesting environment to test this hypothesis. Our results show that, while insiders are generally able to earn abnormal returns, these returns are significantly higher during the years of the financial crisis.
\end{abstract}

Keywords: insider trading, equity markets, market efficiency, information asymmetry, financial crisis, event study, abnormal returns.

Reference to this paper should be made as follows: Van Geyt, D.; Van Cauwenberge, P.; Vander Bauwhede, H. 2013. The impact of the financial crisis on insider trading profitability in Belgium, Journal of Business Economics and Management 14(2): 364-385.

JEL Classification: G01, G14, G18.

\section{Introduction}

In 2007, the subprime mortgage crisis emerged in the US and rapidly spread across the world-wide financial system. This global financial crisis was marked by the failure of several financial institutions and the fast decline of various stock market indices. The financial turmoil led to a chaotic environment in which it was difficult for market participants to determine the fundamental value of companies and their capability to withstand the financial crisis.

An interesting research question against this background is whether the increased uncertainty surrounding the financial crisis enlarged the opportunities of insiders to exploit their informational benefits. Prior studies have already evidenced that insiders are generally better informed about their firm's prospects as they receive relevant information in 
a more timely manner (Ching et al. 2006; Li, Zhang 2006; Cheng, Leung 2008). For example, insiders seem to sell considerably more shares prior to the bankruptcy filing of their company (Gosnell et al. 1992; Seyhun, Bradley 1997). In addition, numerous studies have documented that insiders are able to convert their informational benefit into excess stock market returns (e.g. Seyhun 1986; Lakonishok, Lee 2001; Del Brio et al. 2002; Wisniewski, Bohl 2005; Bajo, Petracci 2006; Cheuk et al. 2006; Betzer, Theissen 2009). Also, using the 1997 Asian financial crisis as a test case, Cheong et al. (2007) and Lim et al. (2008) concluded that the efficiency of financial markets is adversely affected by the occurrence of a financial crisis. Based on these previous findings, we hypothesize that the highly uncertain and volatile stock markets during the recent financial crisis exacerbated the information asymmetry between insiders and other market participants and created additional opportunities for insiders to gain excess returns.

Given the large weight of financial institutions, the Belgian stock market was especially vulnerable to the financial crisis. This provides an interesting environment to test this hypothesis. Using a unique dataset of insider trading transactions in Belgium, we evaluate this research question by testing whether higher abnormal profits were earned during the financial crisis compared to non-crisis periods.

Consistent with previous studies, we proxy the informational advantage of insiders by determining the profitability of their trades (e.g. Frankel, Li 2004; Park, Shin 2009). We apply event study methodology and measure trading profits as the cumulative average abnormal return after the trading event. A correction for thin trading is applied to infrequently traded securities. Furthermore, transactions with overlapping event windows are excluded from the sample to avoid event clustering.

Our empirical findings confirm that during the peak of the financial crisis, insider trading resulted in considerably higher profits. This finding suggests that the crisis enlarged the informational benefits of insiders.

These results are of potential interest to market regulators. They indicate that supervisory authorities should be aware of the greater information asymmetry and stock market inefficiency during a financial crisis. Consequently, stricter enforcement of insider trading regulation and more supervision might be needed during these periods.

Our results are also of importance to companies. Previous research has identified information asymmetry as an important driver of the cost of capital. In addition, Love et al. (2007), and Ivashina and Scharfstein (2010) have shown that credit lines contract in the months and even years following a financial crisis. Consequently, companies have an interest in limiting the informational benefits of their insiders in order to retain a sufficient supply of external capital. Maybe, reducing this information asymmetry could be achieved by increasing corporate transparency.

Our study contributes to the literature in several ways. First, we add to the emerging literature on insider trading in Europe since we are the first to investigate the profitability of insider trading in Belgium. Second, our study identifies crisis periods as an additional driver of insider trading profitability. Previous studies already documented that several firm and trade characteristics influence the information asymmetry between 
insiders and outside, uninformed investors. Higher profits are, for example, earned in small companies (Lakonishok, Lee 2001) and in companies with low market-to-book values (Rozeff, Zaman 1988). Third, our results also contribute to the literature on the efficiency of stock markets during a financial crisis. Cheong et al. (2007) and Lim et al. (2008) provided evidence of increased inefficiency on several Asian stock markets during the 1997 financial crisis. We corroborate and generalize these findings by focusing on the highly developed Belgian stock market during another crisis period.

The remainder of this paper is organized as follows. Section 2 briefly describes the insider trading regulation in Belgium. Section 3 provides an overview of related insider trading literature. Section 4 includes a description of the financial crisis and the hypothesis development. Section 5 discusses the measurement of insider trading profits and section 6 gives an overview of the data collection and sample selection criteria. Section 7 provides some descriptive statistics and finally, section 8 presents and discusses our research results.

\section{Insider trading regulation in Belgium}

The current Belgian legislation on insider trading is founded in the 2003 European Directive on insider dealing and market manipulation, i.e. the Market Abuse Directive ${ }^{1}$. This directive introduced an important amendment to previous regulation by requiring insiders to report their transactions to a competent authority. This notification duty is based on the regulation in the US, where insiders are already required to report their transactions since 1934 under the Securities and Exchange Act.

In Belgium, insiders must notify their trading activity to the Financial Services and Markets Authority (FSMA) which is entrusted with the supervision of the Belgian stock market. They are required to report transactions no later than five trading days following the execution. Afterwards, the FSMA makes the trading activity publicly available on its website ${ }^{2}$. These notification terms are similar to the ones in other European and non-European countries ${ }^{3}$.

\section{Insider trading: literature review}

Research on the profitability of insider trading is essentially based on the efficient markets paradigm. According to this theory, markets are strongly efficient if all information, including inside information, is reflected into stock prices. On the contrary, markets are

\footnotetext{
${ }^{1}$ Directive 2003/6/EC.

2 www.fsma.be

${ }^{3}$ Examples of other reporting requirements: Poland: 24-hours disclosure deadline (Wisniewski, Bohl 2005); Italy: no disclosure required when total quarterly cumulative transactions is below $€ 50000$, quarterly disclosure when between $€ 50000$ and $€ 250000$, and within three business days when above $€ 250000$ (Bajo et al. 2009); UK: insiders must report as soon as possible and no later than five business days after the transaction (Fidrmuc et al. 2006), in addition a black-out period before earnings announcements is imposed (Betzer, Theissen 2009); US: reporting no later than two days following the transaction (Cheng et al. 2007).
} 
perceived as semi-strong efficient if only publically available information is incorporated into prices (Tvaronavičiené, Michailova 2006). As a consequence, insider trading can only be profitable if markets are not strongly efficient.

Early studies investigating the ability of insiders to profit from their trading were concentrated on the US stock markets (e.g. Jaffe 1974; Finnerty 1976; Seyhun 1986; Lin, Howe 1990; Lakonishok, Lee 2001; Jeng et al. 2003). In recent years however, research on insider trading in the European and Asian stock market has emerged. Studies on European stock markets were performed for Germany (Betzer, Theissen 2009), Spain (Del Brio et al. 2002), Poland (Wisniewski, Bohl 2005), the UK (Gregory et al. 1994; Fidrmuc et al. 2006), Italy (Bajo, Petracci 2006) and the Netherlands (Degryse et al. 2009). Studies on Asian stock markets were performed for Taiwan (Chiang et al. 2004), Hong Kong (Wong et al. 2000; Cheuk et al. 2006) and Malaysia (Wong et al. 2010). In general, these insider trading studies support the semi-strong efficient market hypothesis and find that insiders are indeed able to profit from their superior information.

A second evolution in the insider trading literature is the investigation of potential drivers of insiders' profits. First, Jaffe (1974), and Rozeff and Zaman (1988), amongst others, provided evidence that abnormal returns are partly or wholly attributable to latent risk factors like company size and the market-to-book ratio. For example, regarding company size, these studies documented that insiders in small firms earn higher abnormal returns. For these insiders, it is easier to know a significant proportion of all inside information. In addition, prior research has shown that information asymmetries are larger in small companies as they experience less extensive media (Fang, Peress 2009) and analyst coverage (Bhushan 1989; Barth et al. 2001). In later studies, additional firm and trade characteristics were evaluated as potential determinants of insider trading profitability. Examples of such characteristics are the debt-to-equity ratio (Aussenegg, Ranzi 2008), transaction size (Wisniewski, Bohl 2005) and trading intensity (Aussenegg, Ranzi 2008; Betzer, Theissen 2009). Furthermore, some recent studies have started to take corporate governance related variables into account such as ownership concentration (Fidrmuc et al. 2006), type of controlling shareholder (Betzer, Theissen 2009; Bajo, Petracci 2006), board composition (Chang et al. 2005) and executive compensation (Zhang et al. 2005). Chang et al. (2005), for example, investigated whether corporate governance mechanisms which are believed to reduce information asymmetry also reduce to opportunities of insiders to earn excess returns. Their results showed that profits were indeed lower in companies with a higher proportion of non-executive directors in the board and audit committee, in companies where the CEO does not occupy the function of board chair and in companies with lower levels of director and block ownership. Other studies investigating the impact of ownership and control structures include Del Brio and Perote (2007), and Betzer and Theissen (2009). These studies documented that insider trading profits in shares of widely held firms are higher compared to those in controlled companies. Also, Bajo and Petracci (2006) investigated whether institutional investors monitor management more closely and concluded that the presence of an institutional investor among a company's shareholders decreases profits from insider trading. Studies which, like our paper, focus on country-specific or economy-wide determinants are rather limited. In 
general, they focus on differences in the institutional environment such as law enforcement (e.g. Beny 1999; Wisniewski, Bohl 2005), investor protection (Fidrmuc et al. 2011) and stock market characteristics, i.e. emerging versus developed stock markets (e.g. Bhattacharya et al. 2000; Cheuk et al. 2006). These studies found larger trading profits on emerging markets (e.g. Hong Kong: Cheuk et al. 2006) and in countries with weak law enforcement (e.g. Poland: Wisniewski, Bohl 2005).

\section{Financial crisis and hypothesis development}

In 2007, the United States housing bubble escalated into the subprime mortgage crisis. This crisis did not only affect the US stock market but spread throughout the financial system, creating a global financial crisis. Various stock market indices declined rapidly and several financial institutions faced considerable liquidity problems. This crisis was so severe that in several countries, including Belgium, governments and central banks took remedial actions in an attempt to calm the markets and restore confidence in the financial system (European Central Bank 2008). In this chaotic financial environment, investors reacted more nervously to news and experienced more difficulties in ascertaining the fundamental value of companies.

In this paper, we examine whether these turbulent market conditions created additional informational benefits for insiders. Previous studies have already confirmed that insiders possess private information about their companies (e.g. Seyhun 1986; Lakonishok, Lee 2001; Del Brio, Perote 2002; Wisniewski, Bohl 2005; Bajo, Petracci 2006; Cheuk et al. 2006; Betzer, Theissen 2009). In addition, using the Asian financial crisis as a test case, Cheong et al. (2007) and Lim et al. (2008) have documented that the efficiency of stock markets is negatively impacted by the occurrence of a financial crisis. Based on these findings, we expect insiders to earn higher abnormal profits during the financial crisis compared to non-crisis periods.

We address this research question by investigating the profitability of insider trading on the Belgian stock market. In Belgium, the highlight of the financial crisis was situated in the period 2008 and 2009. This is illustrated by Figure 1 which shows a fast depreciation of the BEL 20 Index, i.e. the Blue-chip index for Euronext Brussels, from 2008 until the second half of 2009. Since financial institutions represent a large share of the Belgian market capitalization, the Belgian stock market was especially vulnerable to the financial crisis. At the start of 2008, the three major Belgian banks (Dexia, Fortis and $\mathrm{KBC}$ ) accounted for no less than $36 \%$ of the market value of the BEL 20 Index. In addition, while the EURO STOXX 50 declined by $45 \%$ between the beginning of 2008 and the middle of 2009, the BEL 20 lost $51 \%$ of its value.

To further illustrate the gravity of the crisis in the Belgian stock market, Figure 2 provides the evolution of the BEL 20 Volatility Index. This index is an indicator of investor sentiment on the Belgian stock market. The calculation uses prices of BEL 20 options and is based on the methodology of the implied Volatility Index (VIX) for S\&P500 Index options, i.e. the sensitivity barometer for the US stock market. Figure 2 indicates that Belgian insiders perceived the investment environment as highly uncertain and unstable during 2008 and 2009. Especially at the end of 2008 the Volatility Index rose dramatically. 


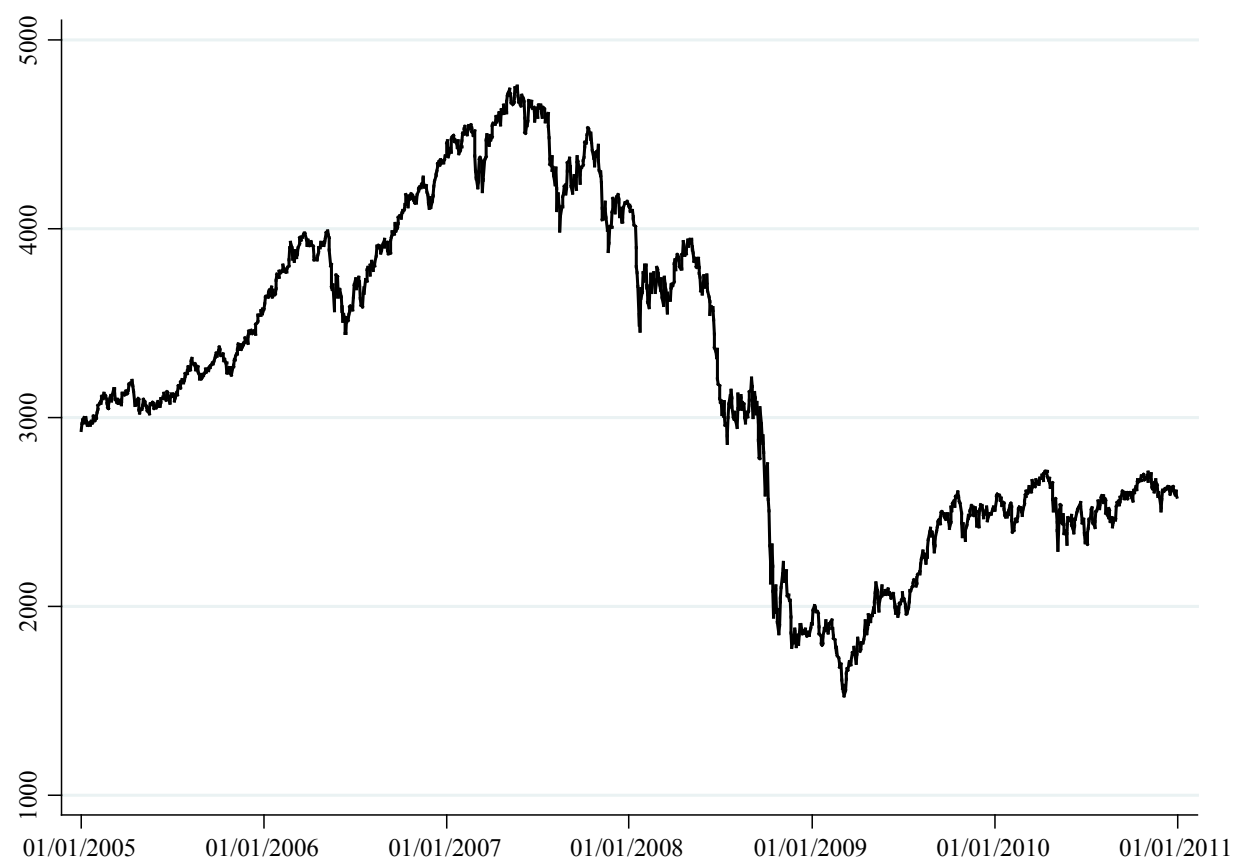

Fig. 1. BEL 20 Price Index

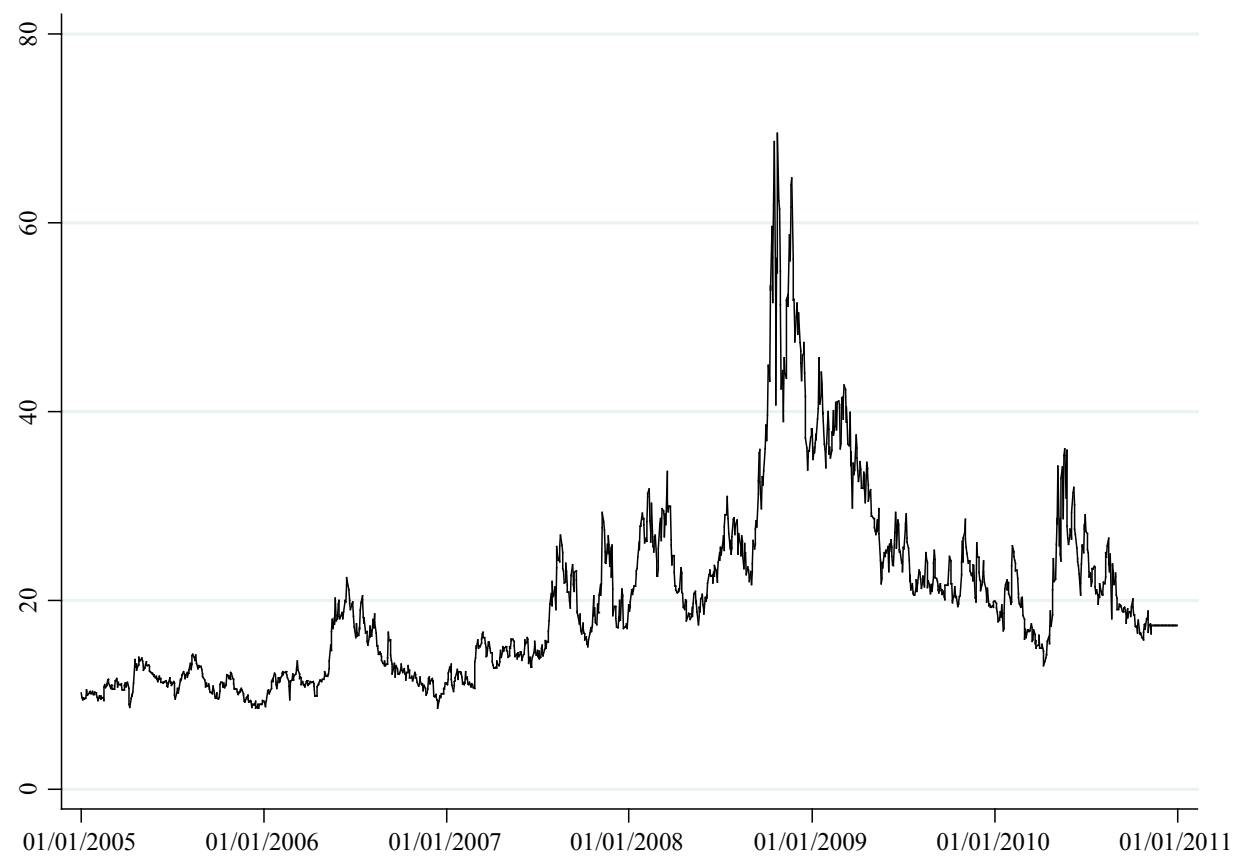

Fig. 2. BEL 20 Volatility Index 
In order to empirically assess the impact of the financial crisis, we compare the profitability of insider trading during crisis and non-crisis periods. We estimate the following OLS-regression and include the dummy variable FinancialCrisis, which is equal to one for transactions carried out during 2008 and 2009 and zero otherwise, i.e. during 2006, 2007, and 2010:

$$
\operatorname{CAR}_{(0,20)}=\alpha+\beta \text { FinancialCrisis }+\gamma x+\varepsilon,
$$

where $C A R_{(0,20)}$ stands for the event-specific cumulative abnormal return over 21 trading days, FinancialCrisis is the test variable and x represents a vector of control variables which are expected to influence the profitability of insider trading. In particular, we included TradeSize, which is measured as the net transaction value scaled by the market value of the company at the beginning of the fiscal year ${ }^{4}$. Previous studies have documented that insiders execute larger transactions if they have stronger beliefs in the future company performance (Karpoff 1987).

FirmSize, which is measured as the log of the market value of equity, is also controlled for as potential information asymmetries are expected to be larger in smaller firms (Grant 1980; Collins et al. 1987; Bhushan 1989). Consequently, insider trading profits should be negatively related to firm size (Seyhun 1986; Finnerty 1976; Betzer, Theissen 2009).

MarketToBook, which is equal to the market value of equity divided by the book value of equity (both measured at the beginning of the fiscal year), is also included. MarketToBook may have a positive association with insiders' abnormal returns as growth firms with high market-to-book ratios have more unrecognized intangible assets and valuable research and development projects. This allows insiders to have greater informational benefits with respect to future prospects and cashflows (Dierkens 1991; Smith, Watts 1992). MarketToBook may, on the other hand, also have a negative association with insiders' gains as previous studies have shown that low market-to-book companies outperform high market-to-book companies, i.e. the value premium (e.g. Rozeff, Zaman 1998; Lakonishok, Lee 2001; Jenter 2005). Therefore, no prediction is made on the relationship between MarketToBook and insider trading profits.

Leverage, which is measured as the debt-to-asset ratio at the beginning of the fiscal year, is controlled for because more levered firms are expected to disseminate more information in an attempt to reduce agency costs. Furthermore, creditors often produce additional information about the borrower in question (Aksu, Kosedag 2006). Firms with higher debt-to-asset ratios are therefore expected to have smaller information asymmetries.

A dummy variable for sales transactions (Sale) is included because sales of Belgian insiders are expected to be more profitable than purchases. In particular, Belgian listed companies are characterized by a highly concentrated ownership structure (Faccio, Lang 2002). Controlling shareholders are expected to refrain from selling unless they have

\footnotetext{
${ }^{4}$ Jenter (2005) argues that it is preferable to measure trade size relative to some measure of wealth or total equity instead of using absolute trade size. The former is assumed to be a more relevant measure of trading behavior.
} 
strong negative believes about the company future. While, regarding purchases, they are expected to more often execute purchase transactions driven by the objective to obtain or maintain corporate control and less by a profit objective.

A dummy variable BanksInsurance, which is set equal to one if a company belongs to the bank or insurance industry and zero otherwise, is also included because of the prevalence of these industries on the Belgian stock market. This approach is in line with Chang and Corbitt who control for the mining and resource industry, which is predominant on the Australian stock exchange.

Next, we also controlled for companies with a concentrated ownership structure. A dummy variable ConcentratedOwn is set equal to one for companies where a shareholder directly or indirectly controls $50 \%$ of the shares and zero otherwise. On the one hand, incentives to monitor the company management may be stronger for dominant shareholders (Del Brio, Perote 2007). However, on the other hand, controlling shareholders may also use their power to privately obtain information and may consequently increase the information asymmetry with other investors (Demetz 1986). Therefore, no prediction is made on the relationship between ConcentratedOwn and insiders' profits.

Furthermore, two variables are included which potentially drive our results regarding the magnitude of insiders' abnormal gains during the financial crisis. First, we expect that the increased uncertainty in financial markets provides additional opportunities for insiders to take advantage of their privileged information. To control for this, we included the BEL 20 Volatility Index as a measure for uncertainty (VolatilityIndex). Second, we control for the number of shares traded per transaction day (InsiderTradesPerDay) as it can be expected that the trading behavior of insiders differs between crisis and non-crisis periods. On the one hand, insiders might increase their trading frequency as the opportunities to obtain abnormal profits are believed to be larger during the financial crisis. On the other hand, insiders may also face a higher risk of prosecution if financial markets are unstable as market authorities are even more on alert for violations of trading regulations and especially for infringements on insider trading restrictions. Consequently, insiders might refrain from trading during a period of financial crisis.

\section{Measurement of insider trading profits}

Consistent with previous insider trading studies, we use event-study methodology to measure abnormal gains from insider trading (e.g. Seyhun 1986; Fidrmuc et al. 2006; Betzer, Theissen 2009). A first step is to calculate the "normal" or "expected" return using a standard market model or a market model adjusted for thin trading (Dimson 1979) as the Belgian stock market consists of frequently traded and thinly traded securities (Buysschaert et al. 2004). When a stock is thinly traded this means that it sometimes does not trade for a prolonged period of time. As a consequence, stock prices might cease to immediately reflect new information. This, in turn, leads to an imperfect synchronization between movements in individual stock prices and the market index because both are recorded over different time intervals. This phenomenon is referred to as non-synchronous trading and causes a downward bias in market model beta esti- 
mates (Scholes, Williams 1977; Dimson 1979). In the Dimson-adjusted market model, stock returns are not only regressed on the contemporaneous market return but also on a number of leading and lagged market returns. Following Buysschaert et al. (2004), we added one leading and three lagged coefficients to the market model for Belgian thinly traded securities. In order to determine for which shares the thin trading model should be used, we follow the approach of Friederich et al. (2002). According to this approach, we sort companies based on the number of zero returns during the estimation and event window. Next, we apply the Dimson market model to companies in the bottom quartile and the standard market model to all other companies.

$$
\begin{array}{cc}
R_{j t}=\alpha_{j}+\beta_{j} R_{m t}+\varepsilon_{j t} & \text { Standard market model, } \\
R_{j t}=\alpha_{j}+\sum_{k=-3}^{+1} \beta_{j k} R_{m, t+k}+\varepsilon_{j t} & \text { Dimson-adjusted market model, }
\end{array}
$$

where $R_{j t}$ is the daily stock return for firm $j$ on day $t$ adjusted for stock dividends, stock splits and issues; $R_{m t}$ and $R_{m, t+k}$ are the daily value-weighed and dividend-adjusted returns on the market index for day $t$ and day $t+k$ respectively. For Belgian listed companies, the benchmark market index is the Brussels All Shares Return Index.

Forecasted "expected" returns are then equal to:

$$
\begin{array}{cc}
\hat{R}_{j t}=\hat{\alpha}_{j}+\hat{\beta}_{j} R_{m t} & \text { Standard market model } \\
\hat{R}_{j t}=\hat{\alpha}_{j}+\sum_{k=-3}^{+1} \hat{\beta}_{j k} R_{m, t+k} & \text { Dimson-adjusted market model }
\end{array}
$$

where $\hat{\alpha}_{j}$ and $\hat{\beta}_{j(k)}$ are estimated over an estimation window of 160 trading days (day -160 to day -1 ) using OLS-regression.

Second, abnormal returns, $A R_{j t}$, are calculated on a company-per-company basis for each day $t$, with $t$ ranging from day zero, the day of the insider trade, to day 20. This event window of 21 trading days is commonly used in insider trading literature (e.g. Betzer, Theissen 2009). It enables us to capture the full market reaction to the insider trade without introducing excessive noise from subsequent events. Abnormal returns are calculated by deducting the forecasted "expected" return from the actual return.

$$
A R_{j t}=R_{j t}-\hat{R}_{j t}
$$

In particular,

$$
\begin{array}{cc}
A R_{j t}=R_{j t}-\hat{\alpha}_{j}-\hat{\beta}_{j} R_{m t} & \text { Standard market model, } \\
A R_{j t}=R_{j t}-\hat{\alpha}_{j}-\sum_{k=-3}^{+1} \hat{\beta}_{j k} R_{m, t+k} & \text { Dimson-adjusted market model. }
\end{array}
$$


Third, the cumulative abnormal return for event $i$ of company $j, C A R_{i j(0,20)}$, is calculated over a time interval of 21 trading days ranging from day 0 to 20 trading days thereafter. This variable is used as the dependent variable in our regression analysis.

$$
C A R_{i j(0,20)}=\sum_{t=0}^{20} A R_{j t} .
$$

Finally, the cumulative average abnormal return over 21 days, $C A A R_{(0,20)}$, is calculated by averaging the cumulative abnormal returns across all events of all companies.

$$
\operatorname{CAAR}_{(0,20)}=\frac{1}{N} \sum_{i=1}^{N} C A R_{i j}
$$

where $N$ is the number of events.

\section{Sample selection}

In our study, we used a unique dataset on the trading activity of Belgian insiders obtained upon request from the FSMA. Data on daily return indices for Belgian companies were gathered from Datastream, while data on the Brussels All Shares Return Index were provided by Euronext Brussels ${ }^{5}$. Both indices are adjusted for dividends as well as stock splits and issues. Furthermore, data on company size and market-to-book and debt-to-asset ratios were collected from Worldscope. Information on company ownership structures was gathered from the Belfirst database of Bureau Van Dijk. Industry classifications were obtained from Euronext Brussels and were based on the Industry Classification Benchmark (ICB).

The initial insider trading database included 4889 insider trades reported between January 2006 and August 2010. Consistent with previous studies, several filters were applied to ensure the quality of our data. In order to focus on trades which are most likely to be driven by superior information, we first excluded all over-the-counter transactions as these are expected to be mainly inter-insider trades. In addition, prices negotiated during these private transactions may differ substantially from the quoted stock prices. This could introduce a serious bias in the estimation of abnormal insider gains as the calculation of abnormal returns is based on market-determined prices. Second, we also eliminated all trades involving the acquisition, exercise or conversion of options, warrants, or scripts. For example, regarding the exercise of stock options, previous studies have documented a high correlation between the exercise of options and the subsequent sale of the underlying shares (Ofek, Yermack 2000). Exercise-events were therefore excluded from the sample in order to avoid double-counting (Huddart, Ke 2007). Third, we deleted transactions that were reported before their execution because, once the information on insider trades is available to other investors, we expect this information to be incorporated into stock prices and to eliminate any abnormal gains.

\footnotetext{
${ }^{5}$ We gratefully acknowledge the assistance of Euronext Brussels for providing the data on the Brussels All Shares Index (ISIN: BE0389550956).
} 
Sample size was also further reduced because we deleted all transactions that were not reported in euros, transactions of companies which were not listed during the entire estimation and event window and transactions of companies which were not included in the Brussels All Shares index. In addition, if insiders of the same company executed more than one transactions on the same day, we calculated net transactions. More specifically, trading volumes were deducted from each other when both purchases and sales were executed on the same day and were aggregated when only one of these transaction types occurred. The calculation of daily net transactions is in line with previous insider trading studies (e.g. Jaffe 1974; Fidrmuc et al. 2006; Betzer, Theissen 2009) and allows us to determine the daily investment consensus among insiders. Transactions with a net transaction size equal to zero were filtered out. Furthermore, we checked for event-clustering on a company-per-company basis. Transactions for a specific company executed within the event-window of a previous insider trade were eliminated from the sample. If we would not adjust for event-clustering, abnormal returns may be biased because they would also reflect the price reaction to trades that were carried out later in the event window. Finally, transactions were deleted because of missing data on control variables. Table 1 provides an overview of the applied filters and the number of deleted transactions.

The final sample consists of 780 firm-year observations of 96 different companies. 427 transactions were executed outside the financial crisis and 353 trades were executed during the financial crisis. Furthermore, 440 transactions $(56.41 \%)$ are net purchases and 340 transactions $(43.59 \%)$ are net sales. In particular, our financial crisis sample consists of 237 net purchases $(67.14 \%)$ and 116 net sales $(32.86 \%)$. The non-crisis sample contains 203 net purchases (47.54\%) and 224 (52.46\%) net sales.

Table 1. Sample selection

\begin{tabular}{ll}
\hline Initial sample & 4889 \\
\hline Applied filters: & 1241 \\
- over-the-counter transactions & 369 \\
- trades not involving buying and selling of common shares & 5 \\
- trades reported before execution & 27 \\
- trades not reported in euro & 128 \\
- trades of companies not included in benchmark & 488 \\
- net transactions & 1760 \\
- event clustering adjustment & 16 \\
- missing stock price data & 5 \\
- net trade value equal to 0 & 70 \\
- missing data on control variables & 780 \\
\hline Final sample & 5 \\
\hline
\end{tabular}




\section{Summary statistics}

In Figure 3, we show the evolution of the cumulative average abnormal returns over 21 trading days. As can be observed in this figure, the cumulative average abnormal returns following purchases and sales display a similar pattern during crisis and noncrisis periods. Consistent with our hypothesis, Figure 3 seems to indicate that during the financial crisis insider purchases yield more positive abnormal returns, while insider sales yield more negative abnormal returns.

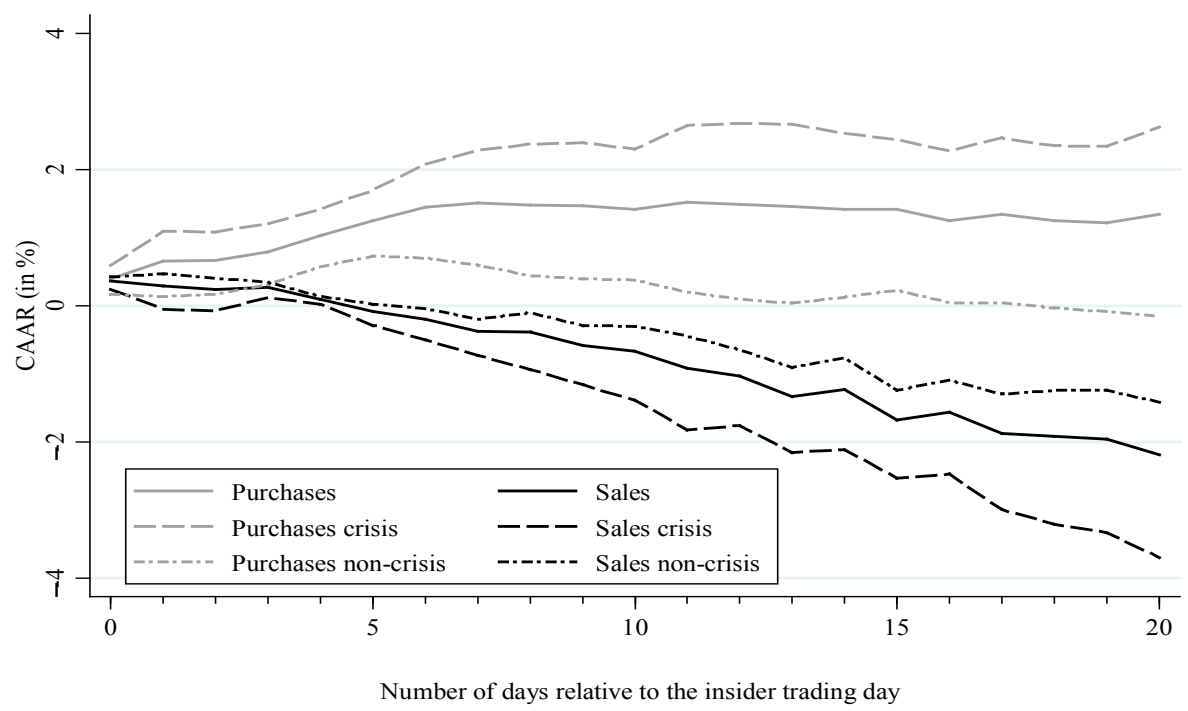

Fig. 3. Post-event cumulative average abnormal returns

In Table 2, we evaluate whether the difference in mean and median cumulative abnormal returns between crisis and non-crisis periods is statistically significant using a univariate t-test and a Mann-Whitney $\mathrm{U}$ test respectively. In Table 2, it can be observed that insider trading profits are higher during the financial crisis. In particular, the mean (median) cumulative abnormal return in the non-crisis period is equal to $0.67 \%(0.34 \%)$ compared to $2.98 \%(0.52 \%)$ during the financial crisis. For insider purchases, the difference between crisis and non-crisis mean cumulative abnormal returns is equal to 2.78 percentage points. For insider sales, this difference is slightly smaller being 2.28 percentage points. For both transaction types the difference in means is statistically significant. When median cumulative abnormal returns are compared, results are somewhat different. Only for purchases the difference between the median CAR during the crisis period $(0.29 \%)$ and non-crisis period $(-0.53 \%)$ is significant at the $10 \%$-level. For insider sales, the median CAR earned during the 2008-2009 financial crisis is 0.74 percentage points higher. This difference is, however, not statistically significant.

Table 2 further also includes descriptive statistics on the explanatory and control variables. In particular, this table shows that insiders do not trade a significantly larger 


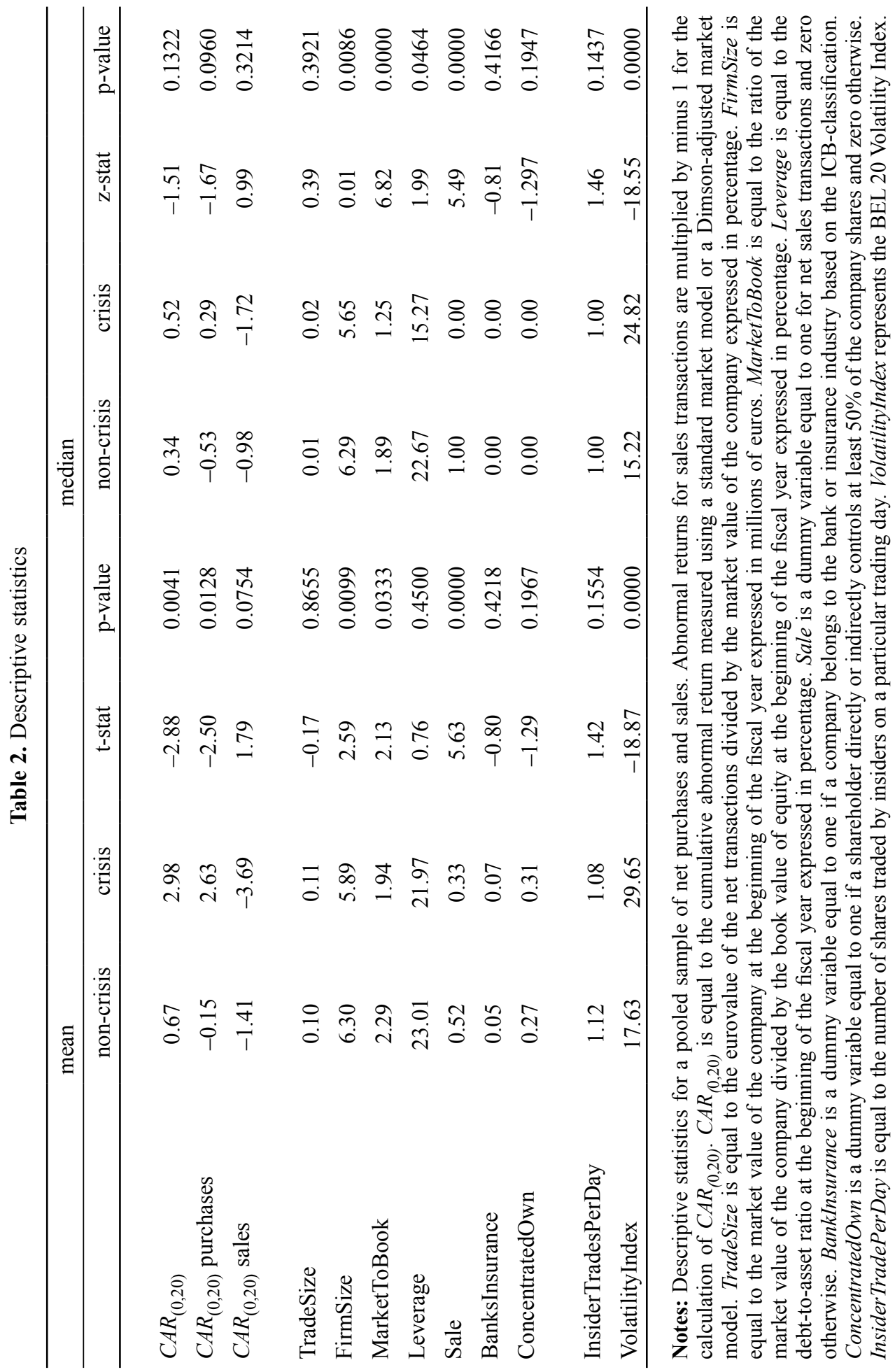


proportion of company shares during the financial crisis (TradeSize) and do not execute more transactions per trading day (InsiderTradesPerDay). Also, notwithstanding the fact that Belgian bank and insurance companies suffered severe losses during the 2008-2009 financial crisis, their insiders did not trade substantially more frequent during this financial crisis (BanksInsurance). Comparing the proportion of sales transactions between crisis and non-crisis periods (Sale), results show that insiders executed relatively less sales during the financial crisis. Finally, crisis-period transactions seem to be concentrated in smaller firms (FirmSize) and in firms with a lower market-to-book value (MarketToBook).

Table 3 contains Spearman correlation coefficients of the regression variables. Based on the reported correlations, no multicolliniarity problems should be expected as the correlations between the independent variables are below the 0.7 limit identified by Kervin (1992).

\section{Results}

In Table 4, OLS-regression results are reported. The CARs for sales transactions were multiplied by minus one because we estimated a single, pooled regression for purchases and sales. Furthermore, standard errors are heteroskedasticity robust and adjusted for clustering at the firm-level (Rogers 1993).

With respect to the control variables our results show that insider trading profits are significantly higher when insiders buy or sell a larger proportion of the company. Transaction size thus seems to be a reflection of the quality of inside information (Karpoff 1987). This result was also found in Seyhun (1986) and Cheuk et al. (2006).

Furthermore, as in other studies (e.g. Gregory et al. 1994; Aussenegg, Ranzi 2008; Betzer, Theissen 2009), insider trading profits are negatively related to the size of the company. Insiders of large companies are expected to have a smaller informational advantage as large companies are more intensely monitored by media (Fang, Peress 2009) and analysts (Bhushan 1989; Barth et al. 2001).

Our regression results also show that the market-to-book value of a company has a significant negative influence on the profitability of insider trading. This finding is consistent with, amongst others, Cheuk et al. (2006), and Betzer and Theissen (2009). Trades in value stocks with low market-to-book ratios thus yield high abnormal returns, while trading in overvalued, high market-to-book companies renders lower abnormal profits.

Furthermore, a firm's financial structure does not seem to influence the magnitude of insiders' gains as the coefficient on Leverage is insignificant. This contrasts prior studies' expectations of less information asymmetry and lower abnormal gains in companies with a higher proportion of debt as both creditors and debtors disseminate incidental information when a company raises debt financing (Aksu, Kosedag 2006).

As expected for insiders of Belgian listed companies, our results show that net sales transactions yield higher abnormal returns than net purchases. Other studies documenting that sales are more informative than purchases include Del Brio et al. (2002) and Cheuk et al. (2006). 


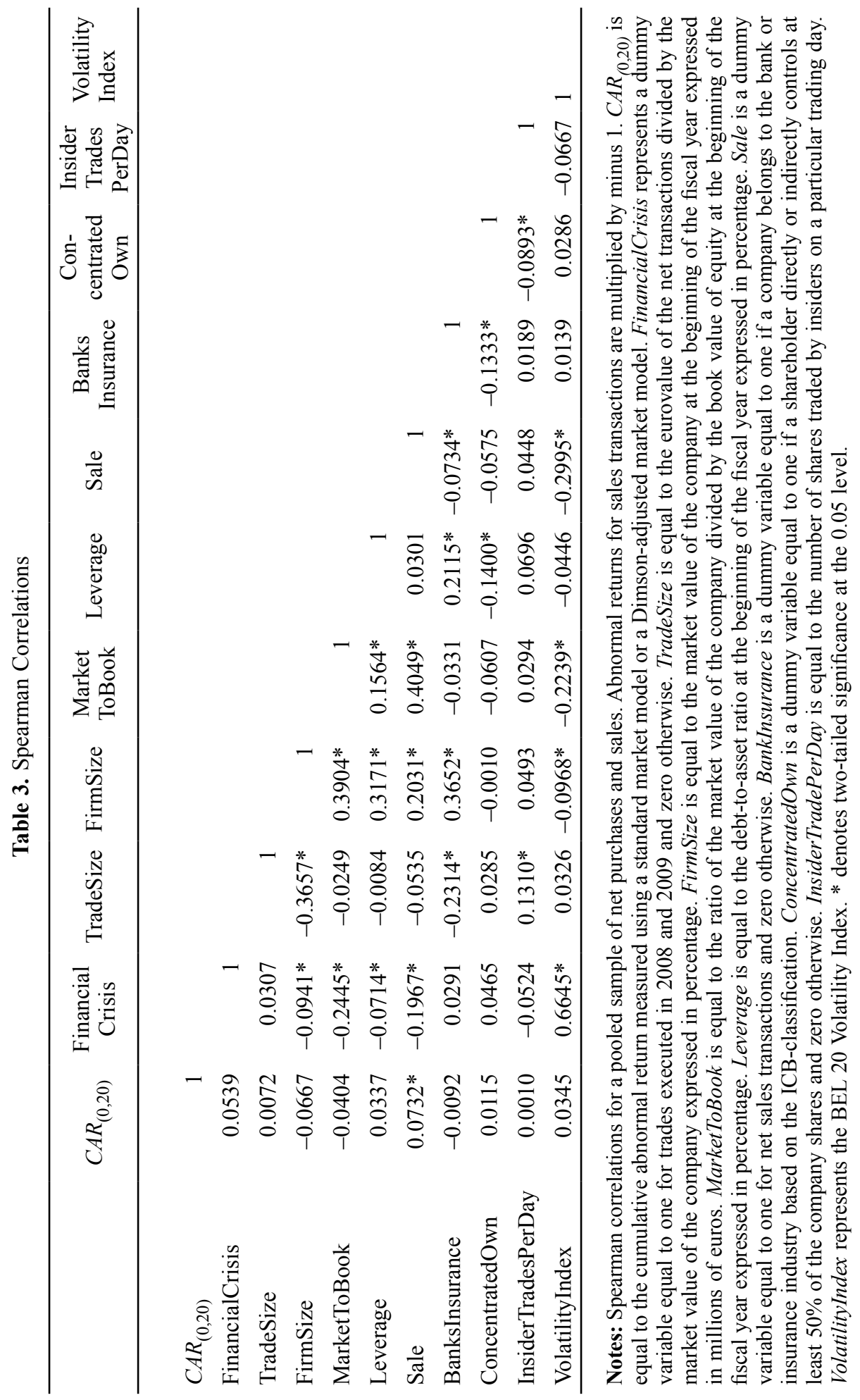


Table 4. OLS regression results

\begin{tabular}{lccc}
\hline Variables & Expected sign & Coef. & s.e. \\
\hline FinancialCrisis & + & $2.032^{* *}$ & 1.098 \\
TradeSize & + & $0.678^{* *}$ & 0.315 \\
FirmSize & - & $-0.749^{* * *}$ & 0.301 \\
MarketToBook & $?$ & $-0.305^{* *}$ & 0.156 \\
Leverage & - & 0.005 & 0.020 \\
Sale & + & $2.673 * * *$ & 0.892 \\
BanksInsurance & $?$ & $2.608^{* *}$ & 1.202 \\
Crisis*BanksIns & $?$ & 3.228 & 5.379 \\
ConcentratedOwn & $?$ & 1.107 & 0.917 \\
InsiderTradesPerDay & $?$ & 1.197 & 0.912 \\
VolatilityIndex & + & 0.012 & 0.056 \\
Constant & $?$ & 2.522 & 2.209 \\
& & & \\
Observations & & 780 & \\
$\mathrm{R}^{2}$ & & 0.047 & \\
$\mathrm{R}^{2}$ adj & & 0.034 & \\
P-stat & & 2.210 & \\
\hline & & & \\
\end{tabular}

Notes: OLS regression results for a pooled sample of net purchases and sales. Abnormal returns for sales transactions are multiplied by minus $1 . C A R_{(0,20)}$ is equal to the cumulative abnormal return measured using a standard market model or a Dimson-adjusted market model. FinancialCrisis represents a dummy variable equal to one for trades executed in 2008 and 2009 and zero otherwise. TradeSize is equal to the eurovalue of the net transactions divided by the market value of the company expressed in percentage. FirmSize is equal to the market value of the company at the beginning of the fiscal year expressed in millions of euros. MarketToBook is equal to the ratio of the market value of the company divided by the book value of equity at the beginning of the fiscal year expressed in percentage. Leverage is equal to the debt-to-asset ratio at the beginning of the fiscal year expressed in percentage. Sale is a dummy variable equal to one for net sales transactions and zero otherwise. BankInsurance is a dummy variable equal to one if a company belongs to the bank or insurance industry based on the ICB-classification. ConcentratedOwn is a dummy variable equal to one if a shareholder directly or indirectly controls at least $50 \%$ of the company shares and zero otherwise. InsiderTradePerDay is equal to the number of shares traded by insiders on a particular trading day. VolatilityIndex represents the BEL 20 Volatility Index. Standard errors are adjusted for firm-clustering and heteroskedasticity. $* * *, * * *$ denote two-tailed significance at the $0.01,0.05$, 0.10 levels respectively when "Expected sign" is a "?" and one-tailed otherwise.

Regarding the profitability of insider trading in bank and insurance companies, our regression analysis indicates that transactions executed by their insiders generate sig- 
nificant higher abnormal returns compared to other industries. Furthermore, as the 2008-2009 financial crisis was denoted as a banking crisis, we also included the interaction of the sector dummy and the financial crisis dummy (Crisis*BanksIns) in order to investigate whether the increased profitability of insider trading during the financial crisis was especially driven by transactions in shares of these financial companies. Our results however indicate that transactions in shares of the bank and insurance companies did not yield significant higher abnormal profits during this period.

Finally, concentrated ownership structures do not seem to affect insiders' abnormal gains as ConcentratedOwn is not significant.

In order to address our main research question, we included a dummy variable which is equal to one when transactions were carried out during the highlight of the financial crisis in the period 2008-2009 and zero otherwise. The significant and positive coefficient on the dummy variable indicates insider trading yielded significantly higher abnormal returns during the financial crisis ${ }^{6}$. Consequently, the financial crisis increased the level of asymmetric information and negatively affected the efficiency of the Belgian stock market. Our research result corroborates and generalizes the findings by Cheong et al. (2007) and Lim et al. (2008) who investigated the influence of the 1997 financial crisis on various Asian stock markets and who find that the level of information asymmetry is higher in times of financial crises.

In order to investigate which factors are potentially driving our results concerning the profitability of insider trading during the financial crisis, we also included the BEL 20 Volatility Index (VolatilityIndex) and the number of shares traded per transaction day (InsiderTradesPerDay) in our regression analysis. With regard to the volatility index, our results show that this index does not have an incremental impact over the financial crisis dummy. So it seems that while the increased volatility over the crisis period, which is reflected by our yearly crisis dummy, is significant in explaining insiders' returns; it is not so that the day-to-day changes in volatility, which are reflected in the volatility index itself, are reflected in changes in insiders' returns once the crisis dummy is included. Also, insider trading activity does not seem to provide incremental information over the financial crisis dummy.

\section{Conclusion}

In this paper, we examined the profitability of trades made by Belgian insiders. Especially, we investigated whether insiders were able to earn higher abnormal gains during the peak of the financial crisis in 2008 and 2009.

Our research results show that, while Belgian insiders were generally able to earn excess returns, the magnitude of their abnormal profits was substantially higher during the years of the financial crisis. Consequently, our findings indicate that the efficiency of the stock market was further deteriorated by the occurrence of the financial crisis.

\footnotetext{
${ }^{6}$ In order to check the robustness of our results, we performed an ANOVA and ANCOVA. Both analyses confirm our results from the OLS-regression.
} 
By evaluating this research question we contribute to the literature in several ways. First, we add to the emerging literature on the profitability of insider trading in European stock markets. Second, our results show that the occurrence of a financial crisis is an important determinant of insider trading profitability. Contrary to our study, prior studies have focused on firm and trade characteristics to explain differences in profitability. Finally, our results also contribute to the literature on the efficiency of stock markets during financial crises. Cheong et al. (2007) and Lim et al. (2008) focused on Asian stock markets during the 1997 financial crisis and found evidence of increased inefficiency. We confirm and generalize their findings by evaluating the efficiency of the highly developed Belgian stock market during another financial crisis.

Our research results also have practical implications. First, they are of potential interest to market regulators. By providing evidence of increased information asymmetry and stock market inefficiency, they indicate that stricter enforcement of insider trading regulation and more supervision might be needed during a financial crisis. Second, our results are also of importance to companies. Previous research has identified information asymmetry as an important driver of the cost of capital. In addition, Love et al. (2007), and Ivashina and Scharfstein (2010) have shown that credit lines contract following a financial crisis. Consequently, companies have an interest in limiting the informational benefits of their insiders in order to retain a sufficient supply of external capital. A reduction in insider trading profitability could be achieved by increasing corporate transparency. The influence of corporate transparency on information asymmetry seems an interesting area for future research.

\section{Acknowledgements}

We gratefully acknowledge the financial support from the "Special Research Fund" (BOF, Bijzonder Onderzoeksfonds) (project: 01J06209) and the "Hercules-project". Furthermore, we thank the Belgian Financial Services and Markets Authority for the provision of the database on insider trading activity in Belgium.

\section{References}

Aksu, M.; Kosedag, A. 2006. Transparency and disclosure scores and their determinants in the Istanbul stock exchange, Corporate Governance: An International Review 14(4): 277-296.

Aussenegg, W.; Ranzi, R. 2008. Corporate insider trading and the short-run price impact of private information in continental Europe, Working paper SSRN-id1265772. Available from Internet: www. ssrn.com.

Bajo, E.; Petracci, B. 2006. Do what insiders do: abnormal performances after the release of insiders' relevant transactions, Studies in Economics and Finance 23(2): 94-118.

http://dx.doi.org/10.1108/10867370610683905

Barth, M. E.; Kasznik, R.; McNichols, M. F. 2001. Analyst coverage and intangible assets, Journal of Accounting Research 39(1): 1-34. http://dx.doi.org/10.1111/1475-679X.00001

Beny, L. N. 1999. A Comparative empirical investigation of agency and market theories of insider trading, Working Paper 264. Harvard Law School [online], [cited 23 March 2010], in John M. Olin Center for Law, Economics and Business. Available from Internet: http://law.bepress.com/ cgi/viewcontent.cgi?article $=1003 \&$ context=umichlwps. 
Betzer, A.; Theissen, E. 2009. Insider trading and corporate governance: the case of Germany, European Financial Management 15(2): 402-429.

http://dx.doi.org/10.1111/j.1468-036X.2007.00422.x

Bhattacharya, U.; Daouk, H.; Jorgenson, B.; Kehr, C. H. 2000. When an event is not an event: the curious case of an emerging market, Journal of Financial Economics 55(1): 69-101.

http://dx.doi.org/10.1016/S0304-405X(99)00045-8

Bhushan, R. 1989. Firm characteristics and analyst following, Journal of Accounting and Economics 11(2-3): 255-274. http://dx.doi.org/10.1016/0165-4101(89)90008-6

Buysschaert, A.; Deloof, M.; Jegers, M. 2004. Equity sales in Belgian corporate groups: expropriation of minority shareholders? A clinical study, Journal of Corporate Finance 10(1): 81-103. http://dx.doi.org/10.1016/S0929-1199(02)00047-0

Chang, M.; Corbitt, R. 2012. The effect of cross-listing on insider trading returns, Accounting and Finance 52(3): 723-741. http://dx.doi.org/10.1111/j.1467-629X.2011.00415.x

Chang, M.; Hillman, R.; Watson, I. D. 2005. Are corporate governance mechanisms effective in reducing insider trading profits?, Company and Securities Law Journal 23(3): 165-180.

Cheng, L. T. W.; Leung, T. Y. 2008. Is there information content from insider trading activities preceding earnings and dividend announcements in Hong Kong?, Accounting and Finance 48(3): 417-437. http://dx.doi.org/10.1111/j.1467-629X.2008.00258.x

Cheng, S.; Nagar, V.; Rajan, M. V. 2007. Insider trades and private information: the special case of delayed-disclosure trades, Review of Financial Studies 20(5): 1833-1864.

http://dx.doi.org/10.1093/rfs/hhm029

Cheong, C. W.; Nor, A. H. S. M.; Isa, Z. 2007. Asymmetry and long-memory volatility: some empirical evidence using GARCH, Physica A: Statistical and Theoretical Physics 373: 651-664. http://dx.doi.org/10.1016/j.physa.2006.05.050

Cheuk, M.-Y.; Fan, D. K.; So, R. W. 2006. Insider trading in Hong Kong: some stylized facts, Pacific-Basin Finance Journal 14(1): 73-90. http://dx.doi.org/10.1016/j.pacfin.2005.06.002

Chiang, M.-H.; Hwang, L.-J.; Wu, Y.-C. 2004. Insider trading performance in the Taiwan stock market, International Journal of Business 3(3): 239-256.

Ching, K. M. L.; Firth, M.; Rui, O. M. 2006. The information content of insider trading around seasoned equity offerings, Pacific-Basin Finance Journal 14(1): 91-117.

http://dx.doi.org/10.1016/j.pacfin.2005.07.002

Collins, D. W.; Kothari, S. P.; Rayburn, J. D. 1987. Firm size and the information content of prices with respect to earnings, Journal of Accounting and Economics 9(2): 111-138.

http://dx.doi.org/10.1016/0165-4101(87)90002-4

Degryse, H.; De Jong, F.; Lefebvre, J. 2009. An empirical analysis of legal insider trading in the Netherlands, Working paper SSRN-id1430283. Available from Internet: www.ssrn.com.

Del Brio, E. B.; Miguel, A.; Perote, J. 2002. An investigation of insider trading profits in the Spanish stock market, Quarterly Review of Economics and Finance 42(1): 73-94.

http://dx.doi.org/10.1016/S1062-9769(01)00103-X

Del Brio, E. B.; Perote, J. 2007. What enhances insider trading profitability?, Atlantic Economic Journal 35(2): 173-188. http://dx.doi.org/10.1007/s11293-006-9060-8

Demsetz, H. 1986. Corporate control, insider trading, and rates of return, The American Economic Review 76(2): 313-316.

Dierkens, N. 1991. Information asymmetry and equity issues, Journal of Financial and Quantitative Analysis 26(2): 181-199. http://dx.doi.org/10.2307/2331264

Dimson, E. 1979. Risk measurement when shares are subject to infrequent trading, Journal of Financial Economics 7(2): 197-226. http://dx.doi.org/10.1016/0304-405X(79)90013-8 
European Central Bank. 2008. Financial stability review December 2008 [online], [accessed 28 January 2011]. Available from Internet: http://www.ecb.int/pub/pdf/other/financialstabilityreview200812 en.pdf.

Faccio, M.; Lang, L. H. P. 2002. The ultimate ownership of Western European corporations, Journal of Financial Economics 65(3): 365-395. http://dx.doi.org/10.1016/S0304-405X(02)00146-0

Fang, L.; Peress, J. 2009. Media coverage and the cross-section of stock returns, Journal of Finance 64(5): 2023-2052. http://dx.doi.org/10.1111/j.1540-6261.2009.01493.x

Fidrmuc, J. P.; Goergen, M.; Renneboog, L. 2006. Insider trading, news releases, and ownership concentration, Journal of Finance 61(6): 2931-2973.

http://dx.doi.org/10.1111/j.1540-6261.2006.01008.x

Fidrmuc, J. P.; Korczak, A.; Korczak, P. 2011. Why are abnormal returns after insider transactions larger in better investor protection countries?, Working paper SSRN-id1344042. Available from Internet: www.ssrn.com.

Finnerty, J. E. 1976. Insiders and market efficiency, Journal of Finance 31(4): 1141-1148.

http://dx.doi.org/10.1111/j.1540-6261.1976.tb01965.x

Frankel, R.; Li, X. 2004. Characteristics of a firm's information environment and the information asymmetry between insiders and outsiders, Journal of Accounting and Economics 37(2): 229-259. http://dx.doi.org/10.1016/j.jacceco.2003.09.004

Friederich, S.; Gregory, A.; Matatko, J.; Tonks, I. 2002. Short-run returns around the trades of corporate insiders on the London stock exchange, European Financial Management 8(1): 7-30. http://dx.doi.org/10.1111/1468-036X.00174

Gosnell, T.; Keown, A. J.; Pinkerton, J. M. 1992. Bankruptcy and insider trading: differences between exchange-listed and OTC firms, Journal of Finance 47(1): 349-362.

http://dx.doi.org/10.1111/j.1540-6261.1992.tb03989.x

Grant, E. B. 1980. Market implications of differential amounts of interim information, Journal of Accounting Research 18(1): 255-268. http://dx.doi.org/10.2307/2490401

Gregory, A.; Matatko, J.; Tonks, I.; Purkis, R. 1994. UK directors' trading: the impact of dealings in smaller firms, Economic Journal 104(422): 37-53. http://dx.doi.org/10.2307/2234673

Huddart, S. J.; Ke, B. 2007. Information asymmetry and cross-sectional variation in insider trading, Contemporary Accounting Research 24(1): 195-232.

http://dx.doi.org/10.1506/0277-1110-4434-M627

Ivashina, V.; Scharfstein, D. 2010. Bank lending during the financial crisis of 2008, Journal of Financial Economics 97(3): 319-338. http://dx.doi.org/10.1016/j.jfineco.2009.12.001

Jaffe, J. F. 1974. Special information and insider trading, Journal of Business 47(3): 410-428. http://dx.doi.org/10.1086/295655

Jeng, L. A.; Metrick, A.; Zeckhauser, R. 2003. Estimating the returns to insider trading: a performance-evaluation perspective, Review of Economics and Statistics 85(2): 453-471.

http://dx.doi.org/10.1162/003465303765299936

Jenter, D. 2005. Market timing and managerial portfolio decisions, Journal of Finance 60(4): 1903-1949. http://dx.doi.org/10.1111/j.1540-6261.2005.00783.x

Karpoff, J. M. 1987. The relation between price changes and trading volume: a survey, Journal of Financial and Quantitative Analysis 22(1): 109-126. http://dx.doi.org/10.2307/2330874

Kervin, J. B. 1992. Methods for business research. New York: Harper Collins.

Lakonishok, J.; Lee, I. 2001. Are insider trades informative?, Review of Financial Studies 14(1): 79-111. http://dx.doi.org/10.1093/rfs/14.1.79

Li, O. Z.; Zhang, Y. 2006. Financial restatement announcements and insider trading, Working paper SSRN-id929539. Available from Internet: www.ssrn.com. 
Lim, K.-P.; Brooks, R. D.; Kim, J. H. 2008. Financial crisis and stock market efficiency: empirical evidence from Asian countries, International Review of Financial Analysis 17(3): 571-591. http://dx.doi.org/10.1016/j.irfa.2007.03.001

Lin, J.-C.; Howe, J. S. 1990. Insider trading in the OTC market, Journal of Finance 45(4): 1273-1284. http://dx.doi.org/10.1111/j.1540-6261.1990.tb02436.x

Love, I.; Preve, L. A.; Sarria-Allende, V. 2007. Trade credit and bank credit: evidence from recent financial crises, Journal of Financial Economics 83(2): 453-469.

http://dx.doi.org/10.1016/j.jfineco.2005.11.002

Ofek, E.; Yermack, D. 2000. Taking stock: equity-based compensation and the evolution of managerial ownership, Journal of Finance 55(3): 1367-1384.

http://dx.doi.org/10.1111/0022-1082.00250

Park, J. C.; Shin, Y. C. 2009. The impact of increased segment disclosure on insider trading profits: evidence from SFAS No. 131, Working paper. Available from Internet: http://www.af.polyu. edu.hk/jcae_af/2010/paper_c/Session\%201A.2.pdf.

Rogers, W. 1993. Quantile regression standard errors, Stata Technical Bulletin 2(9): 19-23.

Rozeff, M. S.; Zaman, M. A. 1988. Market-efficiency and insider trading: new evidence, Journal of Business 61(1): 25-44. http://dx.doi.org/10.1086/296418

Rozeff, M. S.; Zaman, M. A. 1998. Overreaction and insider trading: evidence from growth and value portfolios, Journal of Finance 53(2): 701-716. http://dx.doi.org/10.1111/0022-1082.275500

Scholes, M.; Williams, J. 1977. Estimating betas from nonsynchronous data, Journal of Financial Economics 5(3): 309-327. http://dx.doi.org/10.1016/0304-405X(77)90041-1

Seyhun, H. N. 1986. Insiders' profits, costs of trading, and market efficiency, Journal of Financial Economics 16(2): 189-212. http://dx.doi.org/10.1016/0304-405X(86)90060-7

Seyhun, H. N.; Bradley, M. 1997. Corporate bankruptcy and insider trading, Journal of Business 70(2): 189-216. http://dx.doi.org/10.1086/209715

Smith, C. W.; Watts, R. 1992. The investment opportunity set and corporate financing, dividend, and compensation policies, Journal of Financial Economics 32(3): 263-292.

http://dx.doi.org/10.1016/0304-405X(92)90029-W

Tvaronavičienė, M.; Michailova, J. 2006. Factors affecting securities prices: theoretical versus practical approach, Journal of Business Economics and Management 7(4): 213-222.

Wisniewski, T. P.; Bohl, M. T. 2005. The information content of registered insider trading under Lax law enforcement, International Review of Law and Economics 25(2): 169-185.

http://dx.doi.org/10.1016/j.irle.2005.06.002

Wong, M. C. S.; Cheung, Y.-L.; Wu, L. 2000. Insider trading in the Hong Kong stock market, Asia-Pacific Financial Markets 7(3): 275-288. http://dx.doi.org/10.1023/A:1010009016980

Wong, E. S. K.; Fatt, C. K.; Yap, P. 2010. Disclosure and corporate governance of insider trading: the Malaysian perspectives, African Journal of Business Management 4(9): 1883-1893.

Zhang, W.; Cahan, S. F.; Allen, A. C. 2005. Insider trading and pay-performance sensitivity: an empirical analysis, Journal of Business Finance \& Accounting 32(9-10): 1887-1919.

http://dx.doi.org/10.1111/j.0306-686X.2005.00651.x 
Debby VAN GEYT is PhD Student at the Department of Accountancy and Corporate Finance of the University of Ghent (Belgium). Her research topics include insider trading and corporate reporting.

Philippe VAN CAUWENBERGE (PhD) is Professor at the Department of Corporate Finance and Accountancy of the University of Ghent (Belgium), where he teaches research methods in economics. His work has been published in journals like Public Choice, Abacus, Public Money and Management, Small Business Economics and Accounting and Finance. His research areas are financial markets, insider trading and financial reporting.

Heidi VANDER BAUWHEDE ( $\mathrm{PhD})$ is Assistant Professor at the Department of Accountancy and Corporate Finance at Ghent University (Belgium). She earned her PhD from Katholieke Universiteit Leuven (Belgium). Her main research interests are in corporate governance and corporate reporting (earnings management and disclosure). She has published in various international journals including: Accounting and Business Research, Corporate Governance: An International Review, European Accounting review, Small Business Economics and Accounting and Finance. 